https://doi.org/10.46813/2021-131-050

\title{
VACUUM-PLASMA PROPERTIES OF STAINLESS STEEL AFTER IMPACT OF COMBINED GLOW-MICROWAVE DISCHARGES IN ARGON ATMOSPHERE
}

\author{
G.P. Glazunov, V.E. Moiseenko, S.M. Maznichenko, M.N. Bondarenko, A.L. Konotopskiy, \\ I.K. Tarasov, A.N. Shapoval
}

\author{
Institute of Plasma Physics, National Science Center \\ “Kharkov Institute of Physics and Technology", Kharkiv, Ukraine \\ E-mail: glazunov@ipp.kharkov.ua
}

The experiments were carried out to determine the vacuum-plasma characteristics (mainly erosion and outgassing rate in a vacuum) of the stainless steel $12 \mathrm{X} 18 \mathrm{H} 10 \mathrm{~T}$ before and after processing the walls of the vacuum chamber with the glow discharge and combined, glow-microwave plasma discharges in argon atmosphere. The current-voltage characteristics, the electron density and electron temperature were measured. It was observed that the discharge voltage in the combined regime is significantly lower than in glow discharges. In some modes, this voltage decrease can be up to $200 \mathrm{~V}$. It was shown that erosion of stainless steel $12 \mathrm{X} 18 \mathrm{H} 10 \mathrm{~T}$ in the combined discharges is $\approx 70 \%$, less than in the glow discharges. Measurements were made of the outgassing rate of $12 \mathrm{X} 18 \mathrm{H} 10 \mathrm{~T}$ stainless steel with the thermal desorption probe in situ in the DSM-1 vacuum chamber. It was shown that cleaning the chamber wall by the glow discharge during $5 \mathrm{~h}$ leads to a decrease in the outgassing rate from $5.5 \cdot 10^{-5}$ to $1 \cdot 10^{-5}$ Torr 1$) /\left(\mathrm{scm}^{2}\right)$. When the chamber wall is treated with GM discharge starting from nearly the same initial conditions the outgassing rate decreased to $3 \cdot 10^{-6}$ (Torr 1$) /\left(\mathrm{s}^{\prime} \mathrm{cm}^{2}\right)$. Spectral measurements of the plasma radiation of a glow and combined discharges show a decrease in the ratio of the peaks of argon ions and neutrals during the transition from a glow discharge to a combined one.

PACS: $52.40 . \mathrm{Hf}$

\section{INTRODUCTION}

Vacuum-plasma processes, for example, the outgassing rate of materials in a vacuum, erosion (sputtering), retaining and release of various gases (recycling processes), largely determine the ultimate vacuum in plasma devices and the flows of impurities into the plasma during discharges. One of the main materials of plasma installations is stainless steel (12X18H10T or its analogues St316, St304,), and the vacuum chamber of Uragan-2M stellarator type device (U-2M) is made of it. According to the published data, the specific outgassing rate of untreated, unheated stainless steel after durable pumping is $q \sim 10^{-8}$ Torr $\left.\cdot 1\right) /\left(\mathrm{s} \cdot \mathrm{cm}^{2}\right)[1]$. Assuming the total wall area of the U-2M vacuum chamber of the $F \approx 25 \mathrm{~m}^{2}$ (excluding the surfaces of the branch pipes and the diagnostic tools), we obtain the ultimate pressure in the chamber $P=q F / S \approx 5 \cdot 10^{-6}$ Torr, where $S$ is the pumping speed which is $\approx 500 \mathrm{l} / \mathrm{s}$ in U-2M. Actually, after baking for several days at $\approx 100^{\circ} \mathrm{C}$, "flushing" the chamber with pure nitrogen and a lengthy wall conditioning procedure (mainly cleaning by plasmas with RF or VHF discharges in hydrogen) and pumping out, the ultimate pressure of $1 \ldots 2 \cdot 10^{-7}$ Torr is reached in the U-2M vacuum chamber which corresponds to a specific outgassing rate $q \sim 10^{-10}$ Torr $\left.\cdot 1\right) /\left(\mathrm{s}^{\cdot} \mathrm{cm}^{2}\right)$. Note that longterm heating at $300^{\circ} \mathrm{C}$ results in stainless steel outgassing rates at the level of $4 \cdot 10^{-12}$ (Torr $\left.\cdot 1\right) /\left(\mathrm{s} \cdot \mathrm{cm}^{2}\right)$ [2] However, in most cases it is difficult to implement such a procedure for vacuum chambers of plasma systems. Therefore, the development of technology for cleaning the walls of vacuum chambers (wall conditioning) of plasma systems by other methods, for example, plasma discharges, in order to reduce the outgassing rate in a vacuum, is an actual scientific and technical task. The preceding studies [3, 4] show that the knowledge of outgassing rate of stainless steel, measured in situ in a vacuum chamber, allows not only to assess the degree of contamination of the surface of the vacuum chamber (the number of monolayers of impurities on the surface), but also to evaluate effectiveness of various wall conditioning methods. One of the commonly used wall conditioning methods is glow discharge cleaning in hydrogen or inert gases such as helium and argon [5]. Argon discharge surface cleaning is also widely used in accelerator and spray technology. The disadvantages of the method include a high degree of erosion (sputtering) of materials. In Fig. 1 [6], the sputtering coefficients of metals are shown for $\mathrm{H}^{+}$and $\mathrm{Ar}^{+}$ions taken from various literature sources $[7,8]$. It can be seen that the sputtering coefficient of metals increases by two and for some metals by three orders of magnitude when changing the working gas from hydrogen to argon. Moreover, the sputtering yield by "heavy" ions of erosion-resistant, refractory metals, such as tungsten, rhenium, tantalum, molybdenum, is only several times lower than that easily sputtered, aluminum, copper and silver. To reduce the erosion rate, it is necessary to reduce Ar ion energy. In glow discharge (GD) this can be achieved by reducing the anode voltage, but the GD I-V characteristic prevents this. The GD anode voltage decreasing can be attempted by introducing additional microwave radiation power of the UHF range into the 
GD plasma, in order to run the discharge at lower voltages. At the same time, it is important to provide the quality of wall conditioning not decreasing when processing with a combined GD + UHF discharge, and the erosion rate of stainless steel has to be lower than when processing a wall with a GD.

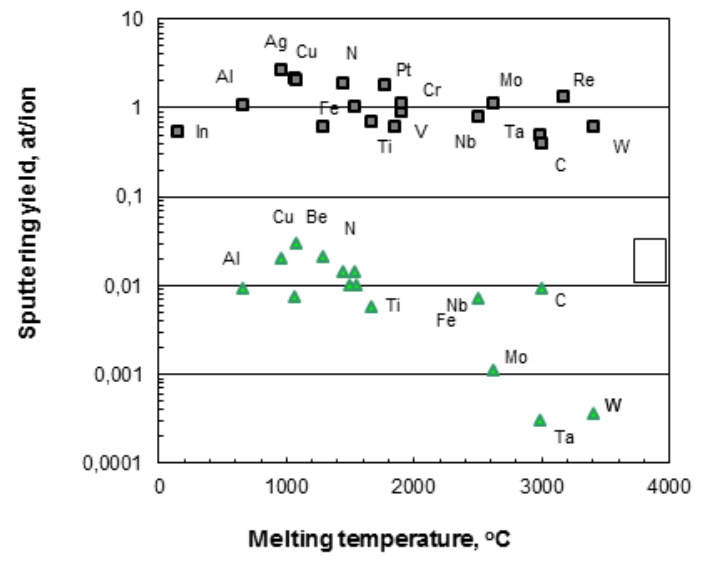

Fig. $1.1 \mathrm{keV} \mathrm{Ar}^{+}$and $\mathrm{H}^{+}$ions induced sputtering yields at normal incidence $[7,8]$ versus melting temperature of various metals [6]

In this work, to solve this problem, experiments were prepared and carried out to study wall conditioning abilities and sputtering properties of GD and glowmicro-wave (GM) discharges on the DSM-1 plasma system.

\section{DESCRIPTION OF THE INSTALLATION, EXPERIMENTAL PROCEDURES}

The DSM-1 plasma installation (diagnostic test bench for materials), on which the experiments were carried out, is described in [9, 10]. At first, it was intended to measure the erosion rate of materials by plasma discharges in crossed electric and magnetic fields (Penning mirror discharge). The scheme and photo of the installation are shown in Figs. 2, 3. The vacuum chamber is made of stainless steel 12X18H10T (hereinafter referred to as SS), unheated, assembled with vacuum rubber seals. The volume of the chamber is $0.35 \mathrm{~m}^{3}$, the wall area facing the plasma is $0.5 \mathrm{~m}^{2}$. The chamber is pumped by a TMP-500 turbomolecular pump (500 l/s pumping speed) and a NVR-5 (5 l/s pumping speed) fore vacuum pump. The ratio of pumping speed TMP to pumping speed of the fore pump is $\approx 100$. This is not a very good option to work with large gas flows. In our experiments it is $0.5 \ldots 30\left(\mathrm{Ncm}^{3}\right) / \mathrm{s}$, and the ratio of at least $20 \ldots 40$ is necessary according to ref. [14]. Otherwise, it is possible to slow down the rotational speed of the TMP rotor, to stop it, the reverse flow of impurities from the fore line to the TMP, etc. Leakage into the chamber volume (leak plus outgassing from the walls) is $\sim 10^{-9}$ (Torr $\cdot 1 / \mathrm{s} \cdot \mathrm{cm}^{2}$ ). After durable pumping the chamber, the ultimate pressure of $\sim 5 \cdot 10^{-6}$ Torr is reached. Then, argon working gas (99.998 vol.) \% was injected into the chamber through the leak to provide a predetermined pressure $\left(10^{-1} \ldots 10^{-3}\right.$ Torr $)$, and the chamber was cleaned with a GD or combined GM discharge. Then the experiments on the SS outgassing rate and erosion rate measurements were carried out.

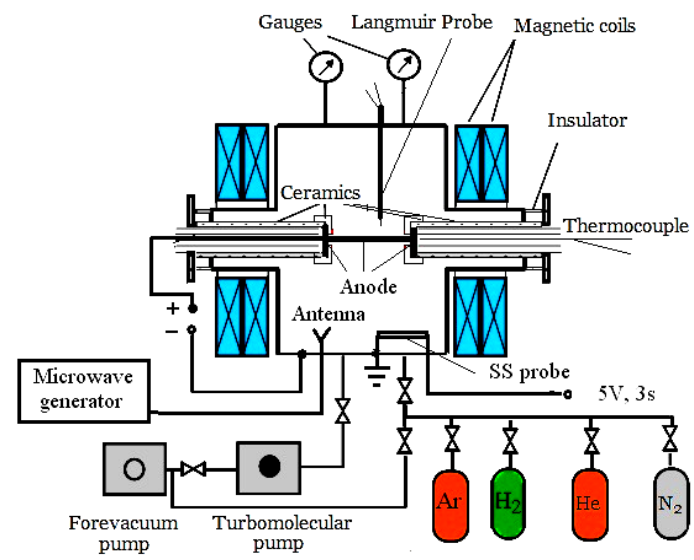

Fig. 2. Scheme of the DSM-1 device

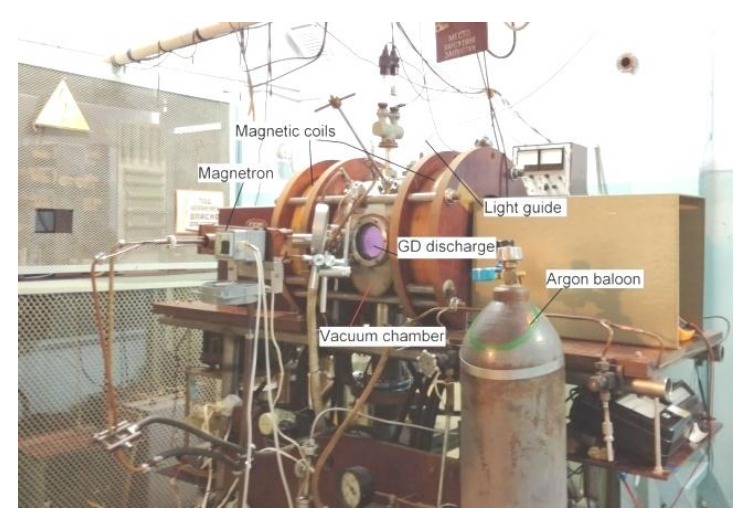

Fig. 3. Photo of DSM-1 device

\section{EXPERIMENTAL RESULTS}

In order to ensure the experiments, the installation was modernized: a Langmuir probe and a multi-grid probe were manufactured and installed in a vacuum chamber, two optical windows for spectroscopic measurements and their protection against sputtering, metal curtains, were installed, the magnetron $(2.45 \mathrm{GHz}, 0.8 \mathrm{~kW})$, and the water-cooled feed-through - antenna system were installed into the chamber DSM-1. The thermal desorption probe diagnostics was installed in the vacuum chamber of the device, which allows measuring the outgassing rate of stainless steel in situ in the DSM-1 vacuum chamber. It includes the stainless steel probe, electrodes, the power supply with a timer, a system for recording pressure changes in a vacuum chamber that includes an ionization lamp, a vacuum gauge, an analog module connected to the computer. A photo of the probe located in situ in the DSM-1 chamber is shown in Figs. 4, 5. The methods for determining the outgassing rate $\mathrm{q}$ of stainless steel and the number of monolayers $\mathrm{N}$ of impurity gases on its surface is described in detail in [3, 4]. The measured value was a pressure change in the vacuum chamber during pulsed heating of the SS probe to the temperature of $250 \ldots 300^{\circ} \mathrm{C}$ (Fig. 6).

Then, such characteristics were estimated as the specific outgassing rate $q\left(\right.$ Torr $\left.\cdot 1 / \mathrm{s} \cdot \mathrm{cm}^{2}\right)$ and the number 
of impurity mono-layers $\mathrm{N}$ on the probe surface according to the technique described in [3]. In this technique the following equations were used: $q=\Delta P \cdot S / F$, where $\Delta P$ is a change a pressure in the vacuum chamber, $S$ is a pumping speed and $F$ is a working surface of $\mathrm{SS}$ probe heated to the temperature of $250 \ldots 300^{\circ} \mathrm{C} ; N=V \cdot L / N_{m}$, where $V\left(\right.$ normal $\left.\mathrm{cm}^{3}\right)=q \Delta t$ is the amount of the gas desorbed from the unitary probe surface, $L$ - number of molecules in the gas volume $1 \mathrm{~cm}^{3}$ (Loshmidts' number), $N_{m}-$ the number of molecules (in terms of water molecules) in the monolayer on the unitary surface.

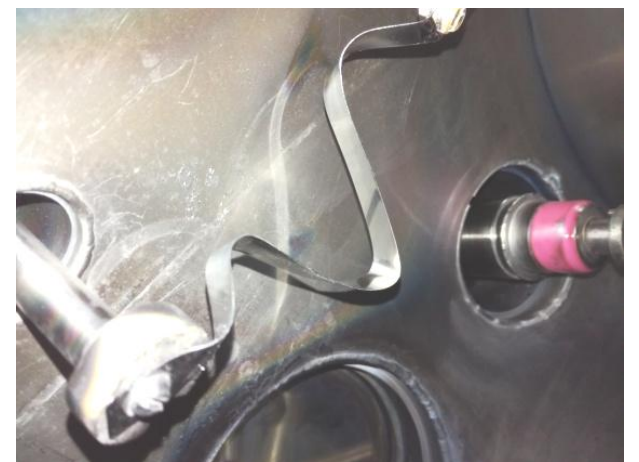

Fig. 4. Thermal desorption SS probe in situ in the DSM-1 vacuum chamber

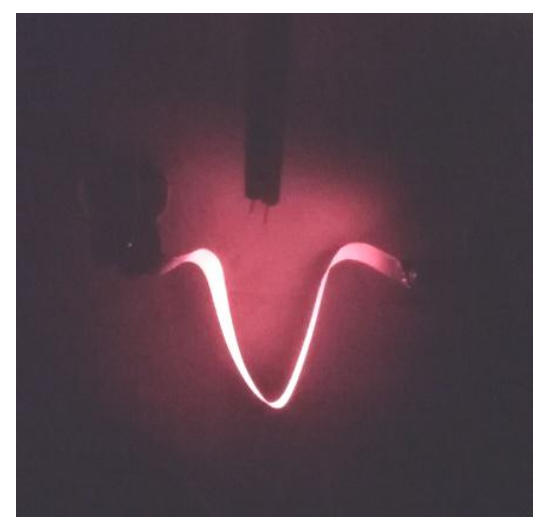

Fig. 5. SS probe under pulse heating up to temperature of $700{ }^{\circ} \mathrm{C}$ in situ in the DSM-1 vacuum chamber

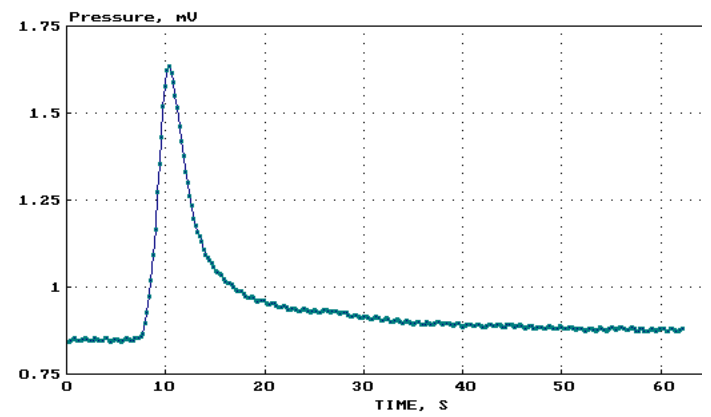

Fig. 6. Apparatus curve of pressure in the DSM-1 vacuum chamber during SS probe heating

After the preparatory work was completed, the DSM-1 installation was transferred from the Penning reflective discharge / magnetron type modes to the glow discharge GD regime. A positive voltage was applied to the two symmetrically placed electrodes and they served as anodes, and the chamber wall served as a cathode and was grounded. The electrodes supplying voltage to the cathodes were isolated from plasma by alumina ceramics. The anodes were two symmetrically placed discs made of the polished stainless steel 12X18H10T (Fig. 7) with a diameter of $25 \mathrm{~mm}$, a thickness of $1.5 \mathrm{~mm}$, or an SS plate $200 \times 10 \mathrm{~mm}$, a thickness of $0.5 \mathrm{~mm}$, with an axial arrangement relative to the chamber walls. A combined discharge was obtained by launching the microwave power from the magnetron generator into the GD plasma. The microwave antenna is shown in the photo (Fig. 8).

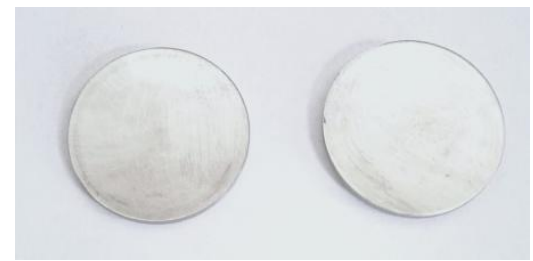

Fig. 7. Anodes for glow discharge

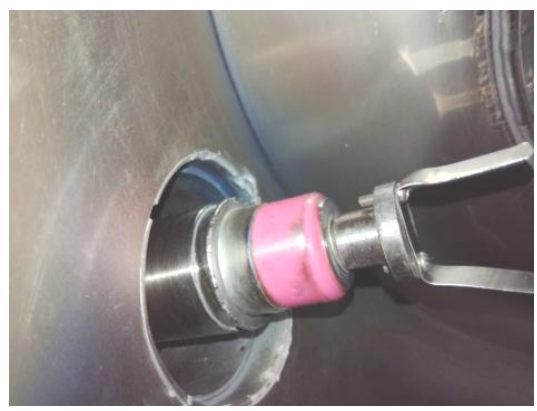

Fig. 8. UHF feed-through with antenna

The operating experience of the UHF feed-through revealed a need to protect its insulator from metal deposition. Quartz cylinders were manufactured and placed on the UHF input (Figs. 9, 10). Because of continuous deposition, time of time they had to be changed or cleaned to remove the deposited film.

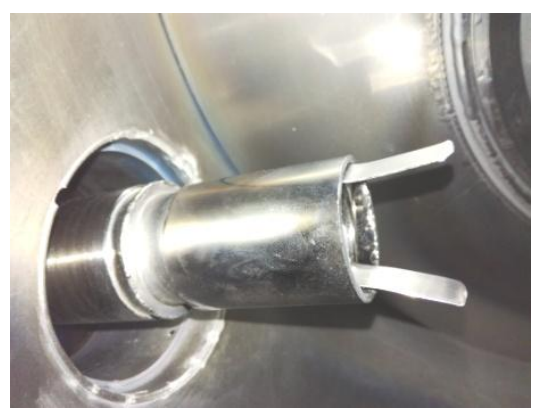

Fig. 9. Anti-spatter UHF input after 20 hours of operation in Ar GD

The sputtering yield of the samples was measured by the weight loss method using a VLR-200 balance, similar to that described in [12]. The samples SS1 and SS2 were two disks made of polished stainless steel 12X18H10T with a diameter of $25 \mathrm{~mm}$, a thickness of $1.5 \mathrm{~mm}$, and the SS3 sample was the plate $300 \times 50 \mathrm{~mm}$, a thickness of $0.5 \mathrm{~mm}$, which were placed on the chamber wall.

The emission spectra from the plasma were recorded through the optical fiber mounted on the upper optical window (see Fig. 3) with spectrometer SOLARTII SL40-2-3648 USB 

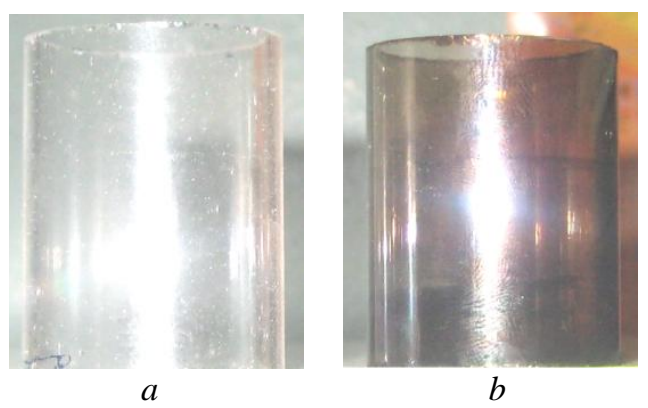

Fig. 10. Quartz cylinders to protect the feed-through insulator from metal deposition: $a, b$-before and after exposure to plasma

Experiments were carried out to determine the plasma parameters: the current-voltage characteristics were measured (Figs. 11, 12), the electron density $n_{e}$ was measured as $\sim 5 \cdot 10^{8} \mathrm{~cm}^{-3}$ for glow and combined GM discharges in argon, and the plasma temperature $T_{e}$ was $\approx 10$ and $\approx 50 \mathrm{eV}$ for GD and for GM discharges, respectively. In the work [14] the equation was suggested for average ion energy in GD $E(\mathrm{eV}) \approx 0.3 \mathrm{eV}$, where $E$ is the average ion energy, $U$ is the cathode voltage. If to use this formula the average ion energy in a GD in our case could be $\approx 110 \mathrm{eV}$ (at a discharge current of $100 \mathrm{~mA}$ ), and in the GM one $\approx 80 \mathrm{eV}$. Analysis of the current-voltage characteristics shows that for the entire pressure range studied, the difference in discharge voltages (at the same current $100 \mathrm{~mA}$ ) is $80 \ldots 100 \mathrm{~V}$. To carry out the procedure of cleaning the chamber wall with stationary GD and combined discharges and measuring the erosion (sputtering) rate of stainless steel, it was necessary to choose the optimal working gas pressure range. The maximum erosion effect will be possible if to clean with GD at relatively low pressures of $\sim 10^{-3}$ Torr, and optimal gas pressure for combined discharge $\sim 10^{-1}$ Torr. In this case, the difference in ion energy can be more than double. But when working with large gas flows, it is necessary to work with strong throttling of the pumping of TMP or even with pumping only by the fore vacuum pump. Moreover, as will be seen from optical measurements, the amount of impurities, mainly water, increases in the chamber due to insufficient pumping. Therefore, to study the cleaning process and erosion, a pressure range of $10^{-3} \ldots 10^{-2}$ Torr was chosen. In this case, the anode voltage difference for the glow discharge and the combined one was $70 \ldots 100 \mathrm{~V}$ (see Fig. 12).

The cleaning procedure was as follows: after pumping and reaching a residual gas pressure of $\sim 5 \cdot 10^{-6}$ Torr, a stationary glow and combined discharges were ignited in two separate experiments. The duration of the treatment of the chamber walls with GD plasma was $6 \mathrm{~h}$. The discharge current in all modes was maintained at $100 \mathrm{~mA}$. This corresponds to the ion current density to the chamber wall $j \approx 12 \mu \mathrm{A} / \mathrm{cm}^{2}$ (it was assumed that $J \approx 0.6 \cdot I$ [14], where $J$ is the ion current to the wall, and $I$ is the measured discharge current). It can be seen in Fig. 13 that cleaning the chamber wall with a GD leads to a decrease of outgassing rate of stainless steel at $300^{\circ} \mathrm{C}$ by about five times - from $5.5 \cdot 10^{-5}$ (Torr $1 / \mathrm{s} \cdot \mathrm{cm}^{2}$ ) up to $1.10^{-5}\left(\right.$ Torr $\left.\cdot 1 / \mathrm{s} \cdot \mathrm{cm}^{2}\right)$. When treating the chamber wall with the combined discharge (the discharge current is the same $100 \mathrm{~mA}$ ), the outgassing decreases to $3 \cdot 10^{-6}\left(\right.$ Torr $\left.\cdot 1 / \mathrm{s} \cdot \mathrm{cm}^{2}\right)$.

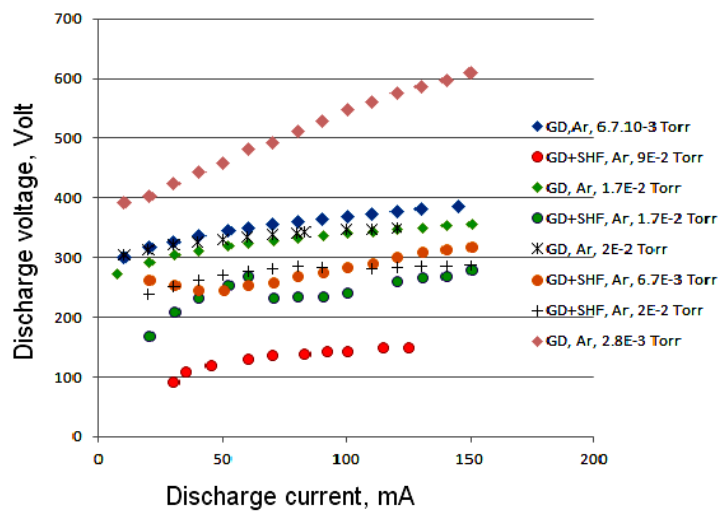

Fig. 11. Current-voltage characteristics of GD and GM discharges at different Ar pressures
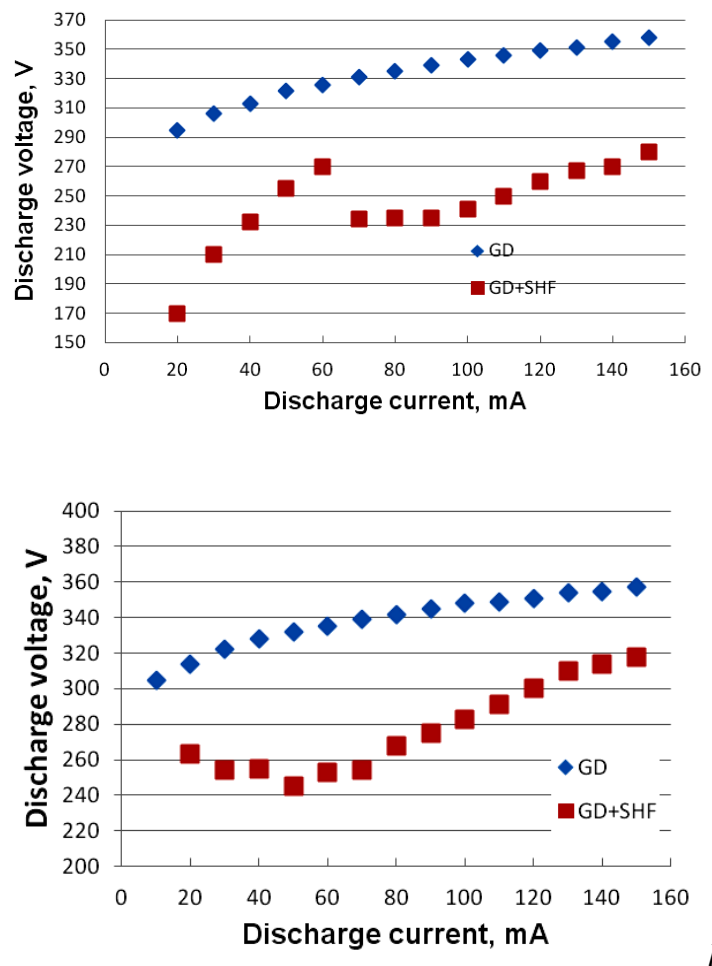

Fig. 12. Current-voltage characteristics of GD and combined discharges at Ar pressures: $a-P=1.7 \cdot 10^{-2}$ Torr and $b-P=6.7 \cdot 10^{-3}$ Torr

So, the cleaning efficiency in the combined discharge is higher. Note also, that the ultimate vacuum in the installation after several discharge cleaning cycles improves from $\sim 5.10^{-6}$ to $1.5 \ldots 2.10^{-6}$ Torr, and the outgassing from the chamber walls decreases from $10^{-9}$ to $8 \cdot 10^{-10}$ (Torr $\left.\cdot 1\right) /\left(\mathrm{s} \cdot \mathrm{cm}^{2}\right)$.

As for the erosion rate of stainless steel, it can be seen from Table, the average sputtering coefficient in the case of plasma treatment with a GD is more than one and a half times higher than when cleaning the walls with a combined GD + SHF discharge. Note thaterosion rate measurements in different modes were carried out at a single pressure of $6.7 \cdot 10^{-3}$ Torr. The 
absolute values of erosion coefficient rather good corresponds to literature data on sputtering yield of $\mathrm{Fe}$ under $\mathrm{Ar}^{+}$ion bombardment with ion energy $\sim 100 \mathrm{eV}$ [16]. Despite the rather high erosion rates of stainless steel, the analysis of the optical spectra (Fig. 15,a) does not reveal presence of metallic impurities in the discharge, for example, $\mathrm{Fe}, \mathrm{Ni}, \mathrm{Cr}$, and also water.

Erosion coefficient of stainless steel 2KH18N10T in various discharge cleaning modes

\begin{tabular}{|l|c|c|c|}
\hline \multicolumn{1}{|c|}{ Plasma treatment mode } & \multicolumn{3}{|c|}{$\begin{array}{l}\text { Sputtering yield, } \\
\text { atoms/ion }\end{array}$} \\
\cline { 2 - 4 } & SS-1 & SS-2 & SS-3 \\
\hline $\begin{array}{l}\mathrm{GD}, \mathrm{Ar}^{+} 12 \mu \mathrm{A} / \mathrm{cm}^{2}, \\
2.4 \cdot 10^{19} \mathrm{ion} / \mathrm{cm}^{2}\end{array}$ & 0.360 & 0.395 & - \\
\hline $\begin{array}{l}\mathrm{Combined} \mathrm{discharge,} \\
\mathrm{GD}+\mathrm{SHF}, \mathrm{Ar}, 12 \mu \mathrm{A} / \mathrm{cm}^{2}, \\
2.4 \cdot 10^{19} \text { ion } / \mathrm{cm}^{2}\end{array}$ & 0.203 & 0.305 & 0.190 \\
\hline
\end{tabular}

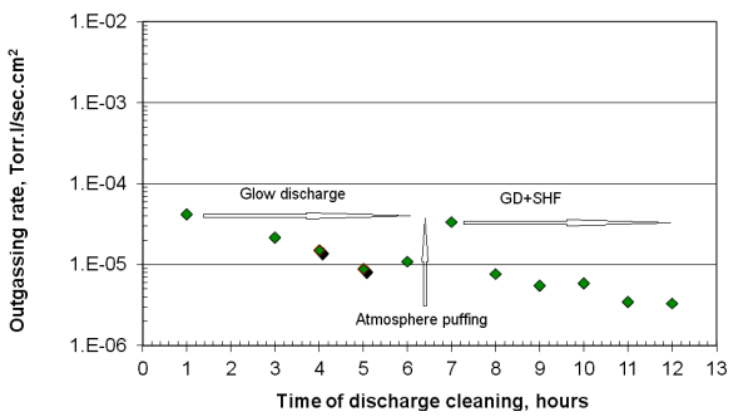

Fig. 13. Specific outgassing rate of 12KH18N1OT stainless steel $\left(300^{\circ} \mathrm{C}\right)$, measured in situ in DSM-1 vacuum chamber vs time of wall conditioning

After wall conditioning experiment the SS thermal desorption probe was demounted and installed in the special bench GAS [3] to measure Ar release under heating. In Fig. 14 the Ar thermal release during SS probe pulse heating to the temperatures of 300 and $500^{\circ} \mathrm{C}$ is shown measured with MX304 quadruple massspectrometer. The nature of the curve in Fig. 14,b means that argon, perhaps, is held in stainless steel in two states with different activation energies of desorption.

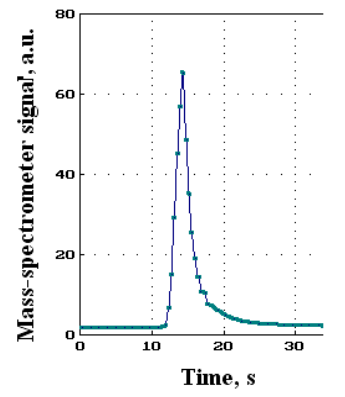

$a$

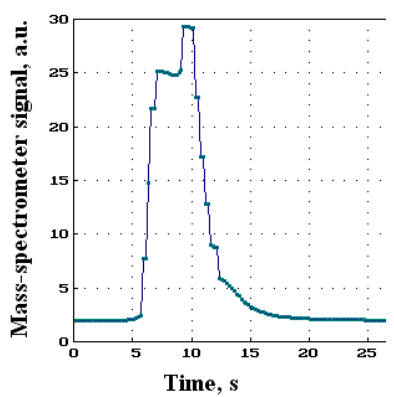

$b$
Fig. 14. Ar thermal release during SS probe pulse heating to the temperatures of $300{ }^{\circ} \mathrm{C}(\mathrm{a})$ and $500^{\circ} \mathrm{C}(\mathrm{b})$

However, if a sufficiently large sample of easily sputtered material is placed into the chamber, in our case it is a copper sheet with dimensions $5 \times 20 \mathrm{~cm}$, then intense copper lines appear in the spectrum (Fig. 15,b). As the working gas pressure increases (the pumping is only with fore pump), intense lines characteristic of water $(\mathrm{OH})$ are detected in the spectra (Fig. 16), which is apparently due to the insufficient speed of the fore vacuum pumping of impurities. Note, the intensity of $\mathrm{OH}$ signal in combined discharges is higher than that for GD. It could say about more effective surfaces treatment with combined discharges. Over time, during discharge cleaning, the intensity of the water lines decreases (see Fig. 16,b) which is indication of the wall conditions improvement.
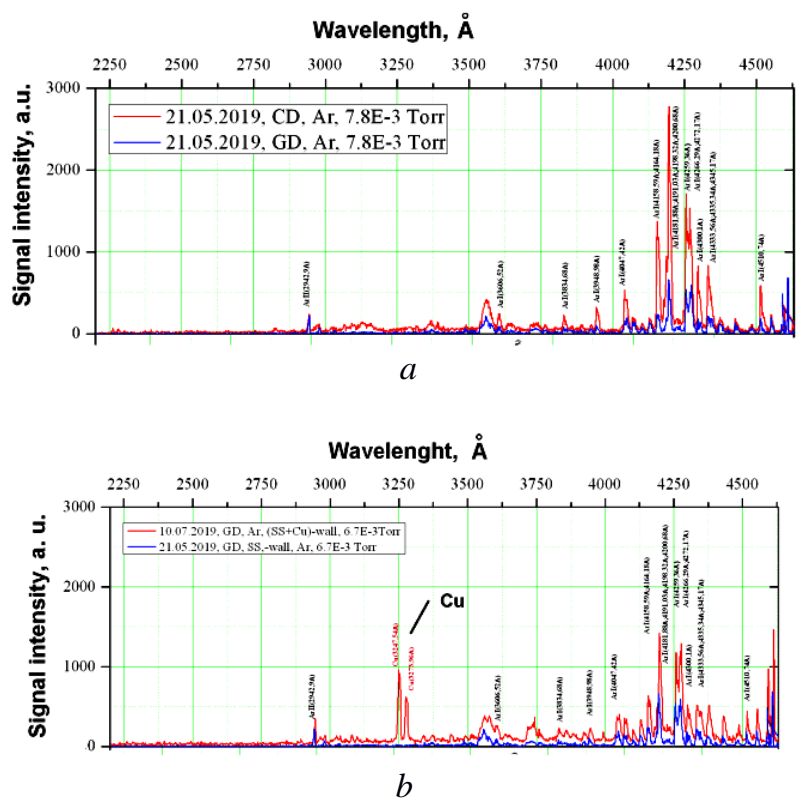

Fig. 15. Emission plasma spectra of glow and combined discharges during pumping of the chamber by a turbo molecular pump, $P_{A r} \approx 7.8 \cdot 10^{-3}$ Torr (a); emission spectrum of a glow discharge plasma in the presence of the copper sample, $P_{A r} \approx 6.7 \cdot 10^{-3}$ Torr $(b)$
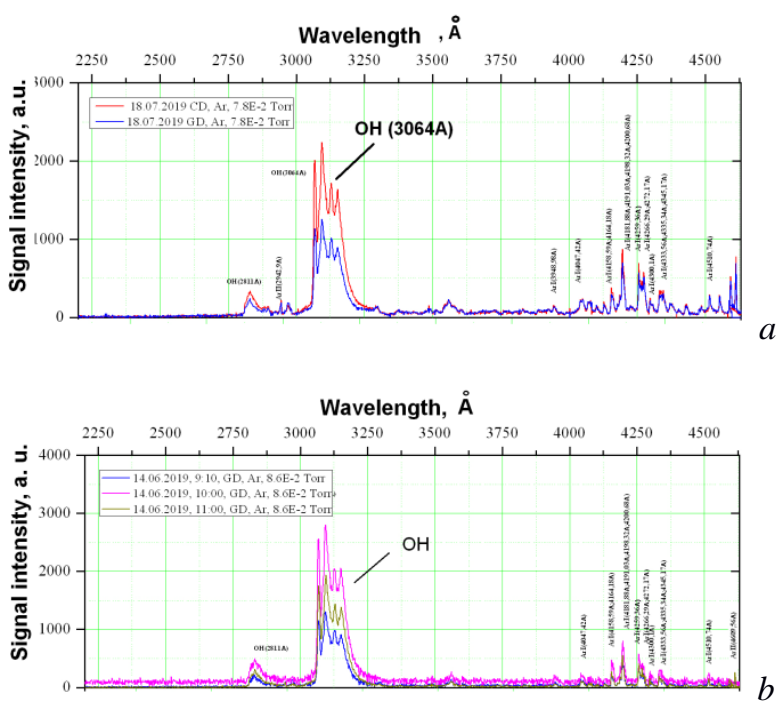

Fig. 16. Emission plasma spectra of glow and combined discharges during evacuation of the chamber by a fore pump (a); spectra of glow discharges vs a cleaning time 


\section{CONCLUSIONS}

Experiments were carried out to determine the vacuum-plasma characteristics (erosion, outgassing rate) of stainless steel before and after wall conditioning of the vacuum chamber of the DSM-1 installation with glow and combined (GD with launching of microwave power) discharges in argon. The current-voltage characteristics, electron density $n_{e} \sim 5 \cdot 10^{8} \mathrm{~cm}^{-3}$ and the electron temperatures $T_{e} \approx 10 \mathrm{eV}$ for glow discharges and $50 \mathrm{eV}$ for combined discharges were measured. It was shown that the discharge voltage in the combined mode is significantly lower (at the same discharge currents) than in GD. In some modes, this reduction can be more than $200 \mathrm{~V}$. It is shown that the erosion of stainless steel in a combined discharge is approximately $70 \%$ less than in a glow discharge at the same discharge current and working gas pressure. The outgassing rate of stainless steel $12 \mathrm{X} 18 \mathrm{H} 10 \mathrm{~T}$ was measured in situ in DSM-1 vacuum chamber. It was observed that cleaning the chamber wall with a GD for $5 \mathrm{~h}$ (discharge current $100 \mathrm{~mA}$ ) results in decrease in the outgassing rate of stainless steel at $300^{\circ} \mathrm{C}$ by about five times from $5.5 \cdot 10^{-5}$ to $1 \cdot 10^{-5}$ (Torr $\left.\cdot 1 / \mathrm{s} \cdot \mathrm{cm}^{2}\right)$. And when treating the chamber wall with the combined discharge with the same start-up conditions (discharge current was the same $100 \mathrm{~mA}$ ) during the same time, the gas release rate drops to the lower value $3 \cdot 10^{-6}\left(\operatorname{Torr} \cdot 1 / \mathrm{s} \cdot \mathrm{cm}^{2}\right)$, i.e. the cleaning efficiency in the combined discharge is higher. The ultimate vacuum in the installation after several cleaning cycles improves from $\sim 5 \cdot 10^{-6}$ to $2 \cdot 10^{-6}$ Torr. Analysis of emission spectra of glow and combined discharge plasma shows a decrease in the ratio of the peaks of argon ions and neutrals during the transition from a glow discharge to a combined one.

Thus, the presented studies show good prospect of using a combined discharge (glow discharge with microwave power launching) in the pressure range of the working gas, argon, $10^{-2} \ldots 10^{-3}$ Torr for carrying out the wall conditioning procedure in plasma devices, e.g., this mode could be tried as one of the possible scenarios for cleaning the vacuum chamber of the Uragan-2M stellarator.

\section{REFERENCES}

1. D.M. Hoffman, B. Singh, J.H. Tomas. Handbook of vacuum science and technology. III. Academic Press, San-Diego, London, Boston, Ney-York, Sydney, Tokyo, Toronto, 1998, $812 \mathrm{p}$.

2. W.G. Perkins. Permeation and outgassing of vacuum materials //J. Vac. Sci. Technol. 1973, v. 10, № 4, p. 543-556.

3. G.P. Glazunov, D.I. Baron, V.E. Moiseenko, et al. Characterization of wall conditions in Uragan-2M stellarator using stainless steel thermal desorption probe // Fusion Engineering and Design. 2018, v. 137, p. 196201.
4. G.P. Glazunov, D.I. Baron, M.N. Bondarenko, et al. In situ quantification of plasma facing surface conditions in the Uragan-2M torsatron // Problems of Atomic Science and Technology. Series «Plasma Physics». 2018, № 1(107), p. 12-16.

5. H.F. Dylla, S.A. Cohen, S.M. Rossnagel, et al. Glow discharge conditioning of the PDX vacuum vessel // $J$. Vac. Sci. Technol. 1980, v. 17(1), p. 286-290.

6. V.A. Belous, M.N. Bondarenko, G.P. Glazunov, et al. Erosion behavior of $\mathrm{W}-\mathrm{Ta}$ coatings in plasmas of stationary mirror Penning discharges //Problems of Atomic Science and Technology. Series «Plasma Physics». 2017, № 1(107), p. 104-108.

7. W. Eckstein, C. Garsia-Rosales, J. Roth, W. Offenberger. Sputtering Data. Munchen: "IPP, Garching". 1993, p. 342.

8. Y. Yamamyra, H. Taware. Energy dependence of ioninduced sputtering yields from monoatomic solids at normal incidence. Research report NIFS, Data series, NIFS-DATA-23. 1995, p. 114.

9. P.Ya. Burchenko, E.D. Volkov, Yu.A. Gribanov, et al. The study of materials erosion in a discharge with oscillating electrons // Sov. J. Tech. Phys. 1985, v. 55, № 11, p. 2097-2288.

10. G.P. Glazunov, E.D. Volkov, D.I. Baron. Effect of Low/High Hydrogen Recycling Operation on Palladium Sputtering under Steady State Plasma Impact // Physica Scripta. 2003, v. 103, p. 89-92.

11. G.P. Glazunov, M.N. Bondarenko, A.L. Konotopskiy, E.D. Volkov. Erosion behavior of tungsten coatings in magnetron type discharges with hot cathode // Problems of Atomic Science and Technology. Series «Plasma Physics». 2008, № 6(58), p. 107-109.

12. G.P. Glazunov, A.A. Andreev, M.N. Bondarenko, et al. Erosion vacuum-arc TiN coatings and stainless steel under impact of steady state plasma of magnetron type discharges // Physical surface engineering. 2011, v. 9, № 3, p. 250-255.

13. G.P. Glazunov, M.N. Bondarenko, E.D. Volkov, A.L. Konotopskiy. Characteristics low temperature plasma of discharges with hot combined cathode in crossed electric and magnetic fields // Proceeding of the International Scietific Conference "Physical and chemical principles of formation and modification of micro- and nanostructures", (FMMN'2008), October 810, Kharkiv, Ukraine, 2008, v. 2, p. 431-434.

14. A.A. Babad-Zakhryapin, G.D. Kuznetsov. Radiation-stimulated chemical-thermal treatment. M.: "Energy Publishing House", 1982, 96 p.

15. J.F. O'Hanlon. Turbomolecular pumps for high gas flow applications // J. Vac. Sci. Technol. 1979, v. 16(2), p. 724-727.

16. Nils Laegreid, G.K. Wehner. Sputtering yields of metals for $\mathrm{Ar}+$ and $\mathrm{Ne}+$ ions with energies from 50 to $600 \mathrm{eV} / /$ J. Appl. Phys. 1961, v. 32(4), p. 365-369. 


\title{
ВАКУУМНО-ПЛАЗМЕННЫЕ СВОЙСТВА НЕРЖАВЕЮЩЕЙ СТАЛИ ПОСЛЕ ВОЗДЕЙСТВИЯ ПЛАЗМЫ КОМБИНИРОВАННОГО ТЛЕЮЩЕГО-МИКРОВОЛНОВОГО РАЗРЯДА В АТМОСФЕРЕ АРГОНА
}

\author{
Г.П. Глазунов, В.Е. Моисеенко, С.М. Мазниченко, М.Н. Бондаренко, А.Л. Конотопский, \\ И.К. Тарасов, А.Н. Шаповал
}

\begin{abstract}
Проведены эксперименты по определению вакуумно-плазменных характеристик (эрозия, газовыделение в вакууме) нержавеющей стали $12 \mathrm{X} 18 \mathrm{H} 10 \mathrm{~T}$ до и после обработки стенок вакуумной камеры плазмой тлеющего и комбинированного (тлеющий разряд с введением СВЧ-мощности) разрядов в аргоне. Измерены вольт-амперные характеристики, электронная плотность, потенциал плазмы. Показано, что напряжение разряда в комбинированном режиме существенно ниже, чем в тлеющем. В некоторых режимах это снижение может быть до 200 В. Показано, что эрозия нержавеющей стали 12Х18Н10Т в комбинированном разряде на $\approx 70 \%$ меньше, чем в тлеющем. Проведены измерения скорости газовыделения нержавеющей стали $12 \mathrm{X} 18 \mathrm{H} 10 \mathrm{~T}$ in situ в вакуумной камере ДСМ-1. Показано, что чистка стенки камеры тлеющим разрядом в течение 5 ч приводит к снижению скорости газовыделения примерно в пять раз - с $5,5 \cdot 10^{-5}$ до $1 \cdot 10^{-5}($ Торр $\cdot \pi) /\left(c \cdot \mathrm{cm}^{2}\right)$. А при обработке стенки камеры комбинированным разрядом за это же время скорость газовыделения снижается до $3 \cdot 10^{-6}$ (Торр л)/( $\left.\mathrm{cm}^{2}\right)$. Проведены спектральные измерения излучения плазмы тлеющего и комбинированного разрядов. Анализ спектров показывает уменьшение соотношения интенсивностей пиков ионов аргона и нейтралов при переходе от тлеющего разряда к комбинированному.
\end{abstract}

\section{ВАКУУМНО-ПЛАЗМОВІ ВЛАСТИВОСТІ НЕРЖАВІЮЧОЇ СТАЛІ ПІСЛЯ ДІЇ ПЛАЗМИ КОМБІНОВАНОГО ТЛІ́ЮЧОГО МІКРОХВИЛЬОВОГО РОЗРЯДУ В АТМОСФЕРІ АРГОНУ}

\section{Г.П. Глазунов, В.С. Моісеєнко, С.М. Мазніченко, М.М. Бондаренко, О.Л. Конотопський, І.К. Тарасов, А.М. Шаповал}

Проведені експерименти з визначення вакуумно-плазмових характеристик (ерозія, газовиділення у вакуумі) нержавіючої сталі 12Х18Н10Т до і після обробки стінок вакуумної камери плазмою тліючого і комбінованого (тліючий розряд 3 введенням НВЧ-потужності) розрядів в аргоні. Вимірювались вольтамперні характеристики, електронна густина, потенціал плазми. Показано, що напруга розряду в комбінованому режимі істотно нижча, ніж у тліючому. У деяких режимах це зниження може бути до 200 В. Показано, що ерозія нержавіючої сталі 12Х18Н10Т у комбінованому розряді приблизно на 70 \% менша, ніж у тліючому. Проведені вимірювання швидкості газовиділення нержавіючої сталі 12Х18H10T in situ у вакуумній камері ДСМ-1. Показано, що чищення стінки камери тліючим розрядом протягом 5 годин призводить до зниження швидкості газовиділення з $5,5 \cdot 10^{-5}$ до $1 \cdot 10^{-5}$ (Тopp·л)/(c·cм ${ }^{2}$ ). А при обробці стінки камери комбінованим розрядом за цей же час швидкість газовиділення зменшується до $3 \cdot 10^{-6}($ Торр $\cdot \pi) /\left(\mathrm{c} \cdot \mathrm{cm}^{2}\right)$. Проведені спектральні вимірювання випромінювання плазми тліючого і комбінованого розрядів. Аналіз спектрів показує зменшення співвідношення інтенсивностей піків іонів аргону і нейтралів при переході від тліючого розряду до комбінованого. 